\title{
Organizing in the Shadow of Academic Entrepreneurship, Excellence and Omnipresence
}

\author{
Farah Dubois-Shaik ${ }^{*}$, Christophe Dubois \\ Faculty of Social Sciences, University of Liège, Liège, Belgium \\ Email address: \\ Fj.shaik@uliege.be (F. Dubois-Shaik), c.dubois@uliege.be (C. Dubois) \\ ${ }^{*}$ Corresponding author
}

To cite this article:

Farah Dubois-Shaik, Christophe Dubois. Organizing in the Shadow of Academic Entrepreneurship, Excellence and Omnipresence. Advances in Sciences and Humanities. Vol. 6, No. 2, 2020, pp. 70-81. doi: 10.11648/j.ash.20200602.13

Received: May 27, 2020; Accepted: June 11, 2020; Published: June 28, 2020

\begin{abstract}
Drawing on an empirical case study conducted in a Belgian University [1], this article proposes a framework to analyze how academic organizations are both structuring and structured by academics' strategies. First, it accounts for three major logics of action - Entrepreneurship, Excellence and Omnipresence - percolating three organizational dimensions - namely managerial discourses, formal and parallel structures [2]. Moreover, this paper proposes that these organizational dimensions constitute three different and always temporary states that are constantly being shaped by three phases of organizing processes namely translation, inscription, enactment [6]. Second, drawing on Gherardi et al.'s metaphor of "shadow organizing" [3], the article identifies some ideal-typical strategies developed by academics: sober stowing away, selecting the local candidate, and invisible caring. The identification of these strategies opens up to discussing how academics are (pretending to) playing and applying the rules of the game, while also disengaging from them. In doing so, academics contribute to preserving and reinforcing the managerial discourse and the formal structure of their organization.
\end{abstract}

Keywords: Academic Strategies, Shadow Organizing, Excellence, Entrepreneurship, Omnipresence

\section{Introduction}

This paper identifies three major logics of action [4] amongst others - that are simultaneously being (re) produced, negotiated, and circumvented by academics' strategies, while structuring academic organizations and contributing to their regulation. Following Crozier [4], a logic of action is a regrouping of tasks performed by individual actors pursuing a common aim, such as teaching, researching, governing, or training for instance. A specific logic brings together all the actors contributing to its realization, beyond their membership in specific subsystems, such as faculties, hierarchical levels, geographical settings, etc. [5]. This paper proposes a framework for analyzing how academics shape and are being shaped by their organization. This framework combines three logics of action - Entrepreneurship, Excellence and Omnipresence, that will be depicted bellow - percolating three organizational dimensions, namely managerial discourses, formal and parallel structures [2].

According to Friedberg [2], organizations are made of three dimensions (see infra, section 4). The first corresponds to the managerial discourses that define the values, the mission and the philosophy of the organization. They characterize the practices of communication, mobilization, representation and legitimation that are undertaken by upper-level employees. The second dimension refers to the formal and visible structure of organizations. It concerns their "materiality", i.e. the codified and official part of the structure of roles, goals and procedures of coordination. This formal structure partly determines, restricts and controls interactions through its business charts, rulebooks and procedures, but also buildings and technological infrastructures, such as Wi-Fi networks, IT solutions and $S A P$ software, which academics must utilize to input their time-sheets, funding and promotion applications, teaching commitments, pedagogical supports, publications, mobility traces, etc. The third dimension is the parallel or hidden structure of organizations. It is an assemblage of the practices and routines that are neither formally written nor officially communicated, but are rather clandestine and hidden by actors, aiming to construct and preserve a space for negotiation and autonomy. This third dimension becomes tangible for actors when they discover, step by step, the rules 
of the game, the organizational culture and the secrets that protect them from the myth of transparency. Gherardi et al. [3] consider that if some of these organizing processes are made visible, some of them constitute shadow organizing. Here, the term organizing collapses "the traditional dichotomy between formal and informal organizations, since central to the process of organizing are the relations forming a seamless web in which organizations are the outcomes of organizing, rather than vice versa" [3]. This paper identifies three ideal-typical shadow organizing practices - the sober stowing away, selecting the local candidate, and the invisible caring strategies (see infra, section 5) - through which academic organizations and logics of action are negotiated, counteracted, adapted, circumvented, but also simultaneously reproduced. As will be discussed in section 5, these shadow organizing practices contribute to reinforce the three academic logics of action.

Second, this paper proposes that these three dimensions (managerial discourse, formal structure, parallel structure) constitute three different and always temporary states that are constantly shaped by three phases of organizing processes [6]. These three phases can be conceived as translation of managerial discourse, inscription of formal structure and enactment of parallel structure. Thus, through these constantly moving phases of organizing, logics of action are created, as actors translate discourses, inscribe rules, and enact informal practices.

These three phases can be illustrated by the following triangle of organizing:

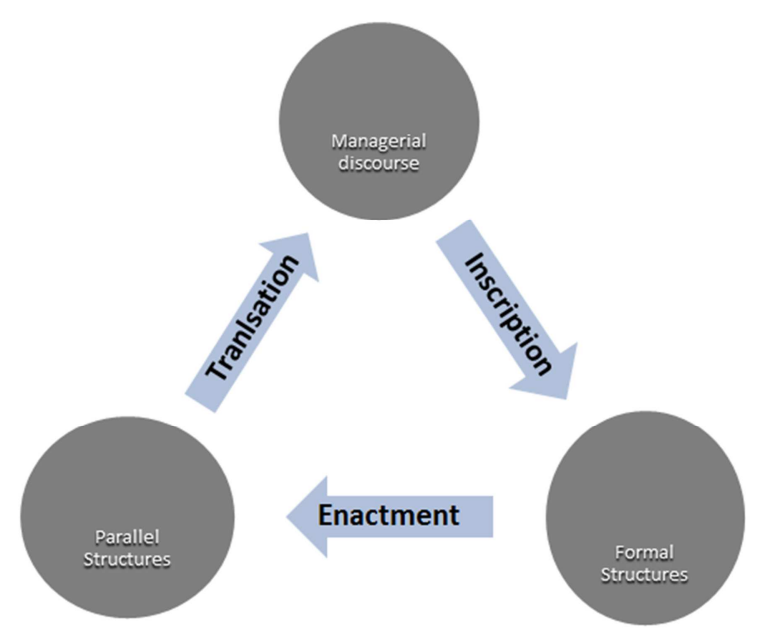

Figure 1. The triangle of organizing.

Analyzing processes of translation, inscription and enactment permitted the authors to identify three (non-exclusive) logics of action named Entrepreneurship, Excellence, and Omnipresence (hereafter EEO logics of action). Drawing on a discourse analysis [7, 8], recurring themes were identified in interview and document material (see infra, 4), and then supported by a literature review.

Although this article is primarily grounded in a Belgian French-speaking University that henceforth will be called Univia, the scope of this study goes beyond this one case study. Firstly, because the political environment has a major influence on the organizing processes of all French-speaking universities in Belgium. Secondly, because some of the organizational observations made here have been shared at the scale of six European universities involved in the original EU FP7 project "Gendering the Academy and Research: Combating Career Instabilities and Asymmetries"1. Moreover, most of the statements made here - especially the identification of the three logics of action - corroborate those made in the Belgian Walloon Region [9], in France [10], in the Netherlands [11], and other quoted colleagues in other European countries.

\section{The Academic Context}

Various authors have demonstrated how, in the last twenty-five years, the decline of budget funding has led to policy reforms based on market discourse [8] in most western countries [12], including in the Belgian higher education system [9]. Universities have "to compete against each other in attracting the 'best' students and scholars as well as funding from the market in order to deliver a high-quality service" [13: 688]. These reforms, reinforced by new public management, contributed to shift academic organizations from a collegial towards a managerialist model [14: 557] driven by a market-oriented regulation $[15,16]$. At the same time, academic funding bodies, governed by researchers, are structuring research performance (see infra) and the institutional norms of academic research, shifting from a collegial to an entrepreneurial ethos [17].

Moreover, in a knowledge economy, industrial and political interests have been integrated in academic research strategies, whereby entrepreneurial scientists [18] are bridging the gap between research and the market [17]. They are guided by public norms promoted by the State and stressing techno-economic renewal and market-determined success [17]. However, despite the illusion of increasing autonomy, academics' entrepreneurship is not only promoted by their will to set up fast-growing spin-off or start-up companies, but rather by their quest for other avenues through which they can pursue their own research interests [19]. There is an increasing reliance on alternate non-university research funding - such as through creating patents, licenses, donations, but also European, national and local public grants. This makes finding financial support a "bidding" concern for research units and their individual members, who "are encouraged to diversify their sources and to build networks of funding", in other words to leverage $[16,20]$. Networks are therefore not only built on research collaborations, but also on funding collaborations that are increasing success in bidding. Research then becomes a highly competitive game in which international standards and indicators gain importance. In this tussle for research funding, collaboration is important, especially in terms of sharing funds within research centers and distributing them according to local needs, as internal (rising number of

1 See $[1,21]$ and www.garciaproject.eu. 
students!) and external candidates for $\mathrm{PhD}$ and postdoc positions are bidding for research contracts. However, bidding for funding is time consuming, and grants are not always - and even rarely - granted. Many academics therefore experience stress in a context where they (and their teams) increasingly depend on particular funders [22], and where performance-based funding transforms research into a source of both reputation and income [12:3]. They are moreover faced with an increasing self-reliance in terms of administrative tasks, and are encouraged to be self-managers [1]. Entrepreneurship, involving bidding, leveraging and collaborating seems to render the academic more dependent and powerless, rather than more autonomous as self-managing would imply. In this context, this paper addresses a first sub question: how are the practices of Belgian academics shaping - and being shaped by -Entrepreneurship?

Various authors have also demonstrated how, in a competitive market, academics must make themselves comparable to other competitors [24] in order to be measured by the yardstick of Excellence indicators and procedures. Excellence appears to be synonymous with the highest achievement on the scale of academic quality [11], or the highest level of academic performance [25] and eminence [26] Like performance and research impact [27], Excellence is, however, "ontologically supposed to be what is summed up by the measurement of "excellence"" [28]. The standards of Excellence are based on Western norms of meritocracy, which refer to a social system that sorts people into positions and distributes rewards solely according to individual performance or talent [29]. According to these standards, academics must be judged on merit alone (e.g. the number of so-called A-ranked journal publications, citation indexes, number of $\mathrm{PhD}$ students, funding grants awarded, cosmopolitanism, etc.), while social categories such as age, gender, race and class should not matter [30]. But if merit indicators and peer review evaluation procedures are two important formal features of academic Excellence, they are interlinked with a network-based system, which does not function simply as a technical tool to measure the quality of academics, but rather as a political device involving negotiations between multiple actors [11]. In Belgium, academic careers and recruitment procedures are therefore fraught with high competition-based schemes [1], where the distribution of performance is extremely unequal [31]. The polysemy of Excellence is problematic "and susceptible to producing radical uncertainty" [32]. Some authors consider that the pursuit of Excellence by universities is based on exclusion mechanisms, and compromises the personal welfare of academics [32]. Belgian scholars have demonstrated that allocating funding on the basis of scientific Excellence criteria contributes to reducing the investment in teaching [9]. In view of these developments, our paper delves into a second sub question: how are the practices of Belgian academics shaping - and being shaped by-Excellence?

In this working context, academics - feel that they - are required to be excellently evaluated according to the classic three pillars of academic work, composed of teaching, research and service activities [33, 34]. Increasingly, Belgian universities make a distinction among service activities as either contributing to internal-institutional governance [35] or participating in external-citizenship commitments [36], conceiving the former as a third pillar, and the latter as a fourth one. Engaging in these three - or four - pillars may leave little room for caring obligations outside academic work. The academic career is therefore "considered as an omnipresent and greedy calling" [37]. From a functionalist perspective, the professional socialization of researchers leads to the learning i.e. acceptance and reproduction - of a specific ethos requiring the demonstration of vocation and total investment in a professional career. Such an ethos emanates from a greedy institution, as noted by Coser [38], and is built on a model of the "man of science", who is entirely engaged in his work, freed from domestic commitments in order to dedicate himself entirely and unrestrainedly to his work. This total engagement in work is considered voluntary and passionate in nature, and modelled on a dissociation of work/family, which is characteristic of a labor society [39]. In the light of an ever-increasing de-institutionalization of the academic profession [40] - driven by mobility, short-term research contracts, few academic positions in relation to the number of doctoral and postdoctoral researchers hired, tougher competition amongst colleagues due to fewer promotions, and relatively short statutory career ladders - the demand for total engagement, or in other words for Omnipresence [21], makes greedy institutions particularly voracious. However, male and female academics consider their work as flexible since they can work from home [1]. But this flexibility often means that the boundary between work and home is nebulous, making the working time borderless. This article thus addresses a third sub question: how are the practices of Belgian academics shaping - and being shaped by - Omnipresence?

\section{Methodology}

This paper draws on a case study conducted in a Belgian French-speaking university, henceforth referred to as Univia, between 2014 and 2017. Two departments within Univia were cross-compared within the university, one in Science Technology Engineering and Mathematics (STEM) and one in Social Science and Humanities (SSH) fields. Governance documents (organizational charts, Codes of order, management rules, Regulations of interior order of councils, etc.) and national and internal funding policy documents (managerial norms of internal resources, narrative data of general financial administrator), and recruitment procedures (documents, statistics, informal reports) have been analyzed, and 80 semi-structured interviews were conducted with

1) 55 (30 female/25 male) researchers and academics;

2) 15 academics and researchers who were committee members for academic recruitment (of which 6 were associate professors and 9 full professors, and one councilor to the rectors' office in matters of recruitment);

3) 10 higher authorities within the different governing levels of Univia (amongst whom were the current 
General Administrator, Vice-Rector of Politics of Personnel, Presidents of Institutes, former Rector, Head of HR).

Furthermore, three focus groups were undertaken with a) doctoral and postdoctoral researchers, b) academics, c) former committee members and former rectors, who had taken part in recruitment procedures, raising the topic of academic excellence and recruitment criteria.

As mentioned, this paper builds on a meta-analysis of research reports (based on aforesaid interviews and focus groups) of a previously conducted and concluded European FP7 study "Gendering the academy and research: combating career instabilities and asymmetries" (GARCIA). This study consisted of an institutional comparison and multi-level analysis amongst six European institutions ${ }^{2}$, in which one of us took part as postdoctoral researcher (having conducted the Belgian case study). Although the focus of the original study has been a gendered perspective of organizational case studies, it primarily drew on sociological and organizational approaches and methods [41]. This primary study therefore used a semi-directive interview grid composed of three themes relating to (1) academics practices (most frequent, most rare, most preferred, most disliked, most important, most meaningless, etc.); (2) academics interactions (what kind, who, most frequent, most rare, most preferred, most disliked, most important, most meaningless, cooperative, conflictual ones, etc.); and (3) work-related opinions (what you like to be changed in the organization? What do you cherish in the organization? What would you like to change in your own way of working? What do you cherish in your own way of working? Etc.). This paper builds on the Belgian case study reports and interview material to do an extensive meta-analysis of academic logics of action [42]. The second author analyzed the original empirical material through an organizational framework [2]. This secondary analysis enabled the identification of the three academic logics of action guiding individual and collective practices and the account of their organizational mechanisms.

\section{The EEO Logics of Action in Univia's Organizational 3Ds}

Drawing on the "organizational 3Ds" analytical framework, this section accounts for the managerial discourse and formal and informal structures conveying Entrepreneurship, Excellence and Omnipresence. The Univia case study can be conceived as paramount to analyze the relationships between - at least - Belgian French-speaking academic organizations, their academics' practices, and their environment.

\subsection{Managerial Discourse, Formal Rules and Informal Practices Related to Entrepreneurship}

The main discursive and formal features composing Univia's policy are related to a triple call to Entrepreneurship,

2 See $[1,21]$ and www.garciaproject.eu. namely to a bidding for funds, leveraging and collaborating with external partnerships, and to self-management of units.

First, the public financing of teaching activities in French-speaking universities is done within a system of "closed envelop", which means that the public authorities have fixed an amount, which is then distributed to the different universities according to their share in the "student market". This system puts the different universities into a competition game to attract students, whereby one university's gain on subsidies will be another's loss. Univia's managerial discourse (deans, general administrator, rectorate, university website) therefore highlights its attractiveness for Belgian and international students, but also for art talents, "sport elites" and "business entrepreneurs". In order to sustain their teaching activities, faculties are therefore venturing towards the multiplication of fashionable and attractive teaching programs, as indicated by the recent rise in Masters' programs and student population. Between 1988 and 2019, the number of students doubled from 52.884 to more than $105.000^{3}$ in the French-speaking Belgian universities, such that Univia hosted, in 2018, around 31.000 students with more than 120 nationalities ${ }^{4}$. Moreover, fewer academics are teaching more students and managing more teaching programs [43]. Some of them invoke this excuse to disengage from research, while others simply delegate the teaching tasks to their research assistants.

"I have always been considering that my main societal and institutional missions are teaching. But the workload related to that mission and the institutional understaffing simply make it impossible for me to invest in research, promote PhDs, publish in major journals, etc. This is a matter of fact, but this also means that I can't apply to get any ordinary professorship. If I had some research assistant, they could take part in my teaching missions, or even publish and I could co-sign. Most of my colleagues are doing so, but I can't, and I don't find this would be fair" (52-year-old male academic, faculty of SSH).

Secondly, leveraging for academics entails creating networks and reliance on private external partners. Moreover, leveraging is seen by the rectorate and deans as a means to compensate for the shortfall caused by the stability of insufficient subsidies for education, as mentioned by the strategic plan of Univia since 2004. A former rector at Univia declared in 2014:

"320 million Euros: this is the annual budget of the university without the research contracts. Two thirds of this budget come from the donations from the French-speaking government. If I refer to the evolution of means in the past ten years, then I have to speak about mediocre means. If one equates these means to the number of students attending the university, there is a decrease of means by about $20 \%$ in ten years. And if one compares the situation to that of other countries, then we are clearly less well off."

3 Source : https://plus.lesoir.be/265808/article/2019-12-10/enseignement-superieur-toujoursplus-detudiants-dans-les-universites. 4 Source : http://www.cref.be/annuaires. 
A major source of external research funding comes from the European Union and is reinforced through explicit reference in Univia's managerial discourse about Europeanisation and internationalization, as mentioned by the Rectorate team:

"We need to increase our attractiveness for international students" and "for international academics"; "Univia decided to invest in European Union research funding"; "We encourage everyone to be involved in the European Network for Higher Education"; "Signing the Euraxess Charter is a major strategic achievement and our Strategic Plan is referring to it as a "code of conduct"'; etc. (Rectorate).

A third managerial and formal normative pattern at Univia concerns an emphasis on the autonomy of research units. On the one hand, this means that research funding is increasingly a matter of the Entrepreneurship or "self-management" of the research units' academic members, while teaching resources are distributed through a bartering system amongst faculties. Funding acquired by the academics themselves makes up an important amount of Univia's financial resources - via the raising of overheads - for sustaining infrastructures and general financial resources [43]. As Univia mainly relies on external research funding, this makes it a "bidding" concern for research units and their individual members, increasingly conceived as entrepreneurs [20,44]. Academics of different levels narrate Entrepreneurship as follows:

"Faculties need to barter out financial resources between themselves" (51-year-old male academic, STEM faculty head).

"The need for economic business partners is vital, especially if we want to promote new spin-offs. Spin-offs are the one best way" (42-year-old male academic, director of research center in STEM faculty).

"As an early-career academic, I need to get big funding as I will be promoted according to my fundability. And of course, I have to do my own managing of my resources in order to employ researchers and create my own research team" (37-year-old male academic, assistant professor in SSH faculty).

Self-management is also inscribed in the formal structures of unit governance ${ }^{5}$, whether they are research, teaching or individual academic and research units. Academics are thus expected to be self-managers, both for applications and for being held accountable, as illustrated by the following section.

\subsection{Managerial Discourse, Formal Rules and Informal Practices Related to Excellence}

The main discursive, formal and informal features composing Univia's policy of Excellence are related to four calls to international visibility, the precedence of research over teaching, network-based systems, and recruitment/evaluation criteria.

First, as already mentioned, academic and/or research candidates must not only "prove" their worth - Excellence - to their Alma Mater, but also to the funding bodies and peer

5 These units can be self-reliant research centers, or loose mini-units composed of project promoters and their junior researchers. review journals funding and publishing their research. Firstly, in terms of Univia's image and institutional position, various discourses on visibility, grandeur, and reputation emerged in the last ten years throughout the documents analyzed and also during the interviews held with top managers. Deans and vice-deans (male and female between 48 to 60 year old) of social science and science and technology faculties unanimously speak about "the need for international visibility"; "the absolute necessity to facilitate Univia's access to the highest international networks of research"; "their will to reinforce a university with an international reputation in matters of teaching and research, favoring international mobility of persons and of knowledge". Univia is involved in European and international ranking systems, such as the Euraxess and Mobility networks, but also in the creation of local networks of higher education (called "Academies" and "Pôles" as required by the so-called Landscape Decree ${ }^{6}$ ).

Second, in the internal valuing of academic tasks, according to academics' discourse, teaching is increasingly under- and de-valued in the academic field, whereby the competition-based idea of Excellence in recruitment and promotion puts all the emphasis on research development and production (publications, mobility, bidding for funds).

"At Univia, I have not yet seen a single promotion to the rank of Professor considering the valuing of teaching activities and initiatives. Only the scientific CV matters" (54-year-old male academic, professor at STEM faculty).

"Fundraising is getting harder. I have just a little help and money to build high quality application files. So far, I have been writing all my applications with my teammates. But we realize that this is becoming more and more technical. If you want to develop the expertise of editing these application files, you really have to specialize. This explains why I had to give up most of my teaching activities" (48-year- old male academic, assistant professor in STEM faculty).

If many interviewees are engaging in teaching tasks, these take second place after research production, as they don't count for career progression. On the contrary, they end up becoming a sticky floor, as interactions with students, although seen as personally rewarding, are not seen as advantageous for the career [43]. As previously discussed, Belgian scholars have discovered that allocating funding on the basis of scientific excellence criteria contributes to reducing the investment in teaching [9]. Paradoxically, in managerial discourse, repeated calls for teaching innovation Entrepreneurship - via Moocs, Spocs, and multimedia platforms are made visible and readable/audible.

Third, an important formal feature of academic work is the publication and funding-evaluation procedures through peer review. Peer-reviewed and impact-factor journals are considered by Univia's community as the more "worthy" publication systems, which validate excellent research and researchers [1, 11]. Peer review allows individual and collective research to be evaluated through an intricate IT system, anonymously, by more than one scientific peer, who

6 http://www.gallilex.cfwb.be/document/pdf/39681_012.pdf. 
read through the article more or less thoroughly, comment on and "validate" for publication (with modifications, rejected, or accepted) in numerous review rounds. Discourse amongst academics/researchers values English-speaking journals rather than French-speaking ones, with a preference for single authored papers and peer-reviewed journals. In short, an academic's list of publications is an important indicator of one's scientific excellence [21] and reinforces the significant political stakes for one's professional future that are at the mercy of peers. Merit indicators and peer review evaluation procedures are two important formal features of academic Excellence. They are interlinked with a network-based system, which consists not simply in a technical tool to measure the quality of academics, but also in a political device involving negotiations between multiple actors [45].

Fourth, the formal guidelines and managerial discourse of Univia promote "open, transparent and merit-based" recruitment practices (OTM-R label delivered by Euraxess). However, as could be observed in several concrete cases (6 recruitment procedures), the recruitment process itself is a heady negotiation process involving mainly locally-appointed academics as selection committees. The committees and the president of the committee enjoy a vast freedom in appointing members (both internal and external), in bartering out the selection process, and in determining the criteria/arguments of what they believe is the suitable candidate for the position (postdoc, and newly tenured positions). These positions, in a first selection round, are subject to rather general, international, and competition-based criteria, compared to more local, institutionally rooted, and nomination-based requirements [43]. Competition-based criteria are mainly used to evaluate candidates in a first selection round through application files. Reviewers value Excellence by evaluating their CVs (mainly publication lists, journal ranks, and citation index), the Excellence of the places where they obtained their Masters and $\mathrm{PhD}$ degrees, and their international mobility (having undertaken research abroad, networks). There is lesser value placed on teaching experience or internal and external community service. There is, however, in the second selection round, as narrated by nine interviewees (35 to 60-year-old male and female academics in both STEM and SSH faculties, recruitment committee members), more emphasis on local criteria, such as the capacity of the candidates to work in a team and integrate in the local departmental culture; their capacity to fit in and to not be a solo-player; their capacity to not see Univia as a transitory path to other horizons; their capacity to teach mainly in French - etc.

In line with this analysis, it can also be presumed that the norm of Excellence is also at play in promotion and hiring processes for academics climbing their career ladders.

\subsection{Managerial Discourse, Formal Rules and Informal Practices Related to Omnipresence}

The main discursive and formal features composing Univia's norm of Omnipresence are related to an integrated monitoring system, a meeting-based system of governance, the promotion guidelines, and a socio-material infrastructure allowing flexibility.

First, the administrative monitoring of academic inputs and outputs enables administrative employees to elaborate dashboards on the basis of the inputs provided by self-managers in intricate internal IT systems, such as the SAP software ${ }^{7}$. These dashboards then enable the administration to classify academics according to their engagement in the three pillars, their status, webpage, remuneration, courses, communication with and evaluation by students, announcements, time-sheets and recording of research income, income management, continuous recording of publications, etc. This amounts to an integrated - "panoptic", according to some academics - system of accountability that can be followed up and monitored by the administration at any time. The formal structure at Univia shows that logistic support is increasingly centralized to cater to the needs of the central administration. Parallelly, most interviewed academics speak about a lack of administrative and technical support while estimating that administrative procedures constitute $60 \%$ of their work [1].

Second, a meeting-based governing system can be observed, entailing various requirements to attend council meetings, meetings with other academics and researchers in order to coordinate and collaborate teaching programs, scientific - and evaluation - boards, working groups, follow-up committees, etc. Many academics experience an increasing pressure to be permanently available, and to promptly answer emails coming from institutional, scientific and teaching networks. They also speak about how they are expected - by their dean, president, and colleagues - to "attend every council meeting", "arrange numerous meetings", and "constantly answer emails, fill doodles, otherwise dropping out of the communication system".

"The time devoted to the institution, the faculty or the department, doesn't pay back in terms of scientific reputation, nor in terms of research and publication obviously. This time is dedicated to endless and boring meetings and readings. Are these essential to run the shop?" (46-year-old male academic and dean of SSH faculty).

Third, all the interviewees acknowledge the importance of being engaged in the three - or four - academic pillars, as they structure the evaluation/promotion guidelines, and provide meaningful work. However, they also express the frustration caused by the norm of Omnipresence in multiple tasks and arenas. This norm does not leave sufficient time for research development or for publication - the overarching criteria for career advancement. Qualifying for a promotion therefore means dedicating oneself to multiple tasks [21, 39], with a discourse of "total engagement" carried out by heads of departments. Most interviewees expressed what is "considered as an omnipresent and greedy calling" [37, 38], and some of them pointed to the fact that heads of departments, scientific board members and rectorate are seen as "the most assiduous attendants because they are often relieved of scientific and educational duties".

"If some colleagues really manage to be omnipresent, most

7 Systems Applications and Products in Data Processing. 
are just acting as if they were: you can actually sign publications you didn't write, go to conferences without presenting anything, be substituted in your teaching tasks without mentioning it, passively attend a meeting without taking part in it because you are working on your laptop, be part of a board without attending its meetings, etc. You can always simulate, do as if, or play the empty chair game. The more commitments you have, the easier it is." (52-year-old male academic, professor at SSH faculty).

On the other hand, academics also make themselves visible as "proactive academics" on social media, such as Twitter or Facebook or personal webpages, illustrating their Omnipresence in multiple engagements.

Fourth, flexibility is another motto in the managerial discourse. Academics consider research and preparing teaching as quite flexible in terms of working time and space, as Internet and digital libraries allow them to work from home. But this flexibility is double edged since it is also considered "elastic":

"I work from home, but that means that I'm always working in some sense, and I have the impression of never stopping" (36-year-old female academic, postdoctoral researcher and lecturer at SSH faculty).

IT systems increasingly provide the material infrastructure allowing such flexibility, increasing academics' feeling that they need to respond immediately and at any time. The automatic response setting in emailing systems is seldom used during holidays or leaves, and they always imply some access to the mailbox. Average academic working hours at Univia are estimated at 45 hours per week despite a contract of 38 hours. This is not considered as something negative, but as "part of the academic profession", for which most interviewees (in both STEM and SSH, male and female) express a "vital passion". In such a working context, academics have an increasing workload as they experience the requirement to be omnipresent [1] in the classic three pillars of academic work.

\subsection{EEO logics of Action According to the 3D Analytical Framework}

The table below (Table 1) maps the three EEO logics of action, within which academics define their own practices while shaping academic organizational structures, according to an organizational 3Ds framework as discussed supra (1.1).

Table 1. Tables may span across both columns.

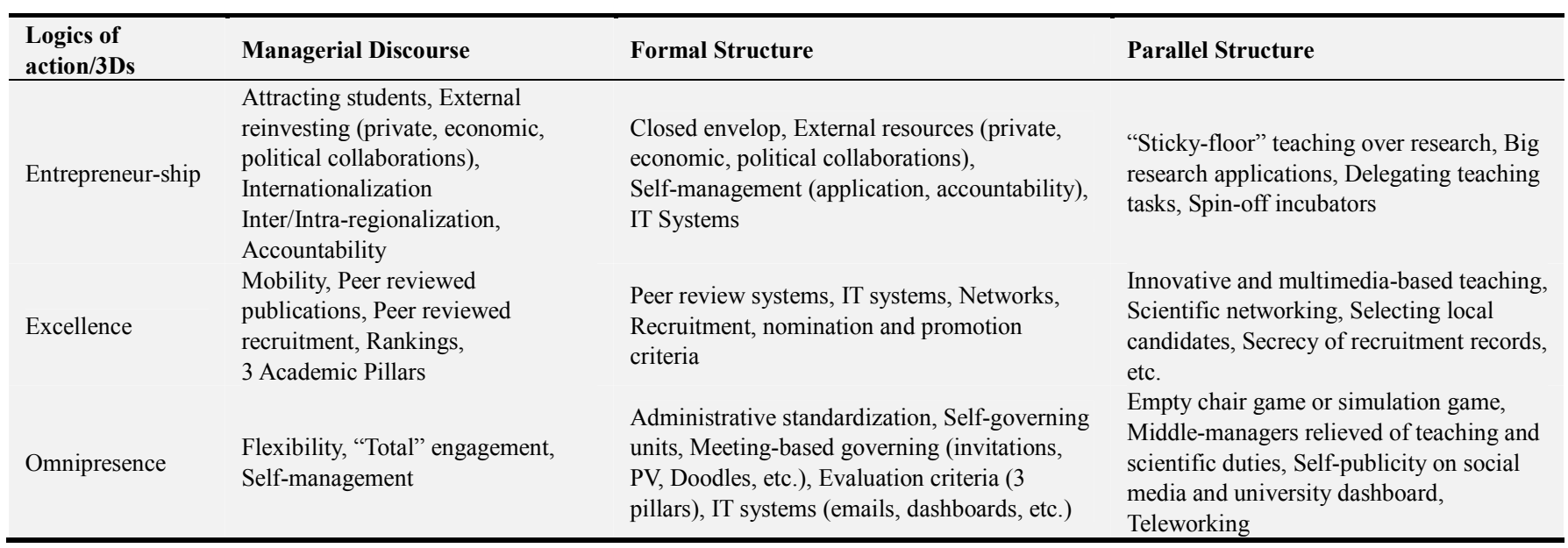

As shown, these 3Ds do not coincide with the hierarchical layers in the organization: they percolate through the levels of organizational charts, and thus they concern academics at different governing levels in the academic organization, i.e. top, middle and self-managers according to entrepreneurial discourse. Some gaps lie between these three dimensions, because the members of an organization don't always do what they are meant or told to do, nor do they always do what they have to do. "Organizational hypocrisy" [43] is a title for such gaps that are generated because not all actors share the same logic. Academics are simultaneously producing these gaps while trying to resist them, or work around them. Following Gherardi et al. [3], we consider that the term "organizing" collapses "the traditional dichotomy between formal and informal organizations, since central to the process of organizing are the relations forming a seamless web in which organizations are the outcomes of organizing, rather than vice versa". This matrix illustrates how EEO logics of action are enacted, inscribed, and translated by academics. And the following section describes how they negotiate, adapt, and circumvent these three logics of action, whilst at the same time shadow organizing contributes to reproducing them.

\section{Three Ideal Types of Shadow Organizing Practices}

Drawing on Gherardi et al. [3]'s metaphor of "shadow organizing", this section accounts for three ideal-typical shadow organizing practices consisting of sober stowing away, selecting the local candidate, and invisible caring ${ }^{8}$. Shadow organizing practices therefore reveal how academic organizations and logics of action are negotiated, adapted and

8 As for the three logics of action, the terms used for the three types of shadow organizing that were identified were gleaned from interviewees own wordings, then supported by relevant literature. 
circumvented. The metonymy of the "shadow" refers to

"the rich ecological conditions that harvest different forms of life, whereby all the participants (human and non-human) intra-act in a sheltered environment, without binding commitments, and, at the same time, the ground for such connections is nurtured by the presence of the formal organizing mechanisms and institutions and their modes of fostering other experiences" [3: 7].

Gherardi et al. distinguish between three metonymies of the shadow: "the forest and its sheltered spaces in penumbra; the shadow as a liminal, grey zone between canonical and non-canonical practices; and secret societies, hidden in the shadow" [3: 11]. These three metonymies aim at accounting for the arrangements through which actors manage to structure some spaces enabling them to negotiate between themselves and the formal rules of the game [41].

\subsection{Sober Stowing Away in the Penumbra of Entrepreneurship}

The "penumbra" metonymy [3] illuminates how individual academics can cope with and pretend to contribute to the Entrepreneurship logic of action, as illustrated by a concrete strategy that will be called "sober stowing away".

Gherardi et al. [3] mention that organizing processes take place "in an ecological niche." And that a "protective penumbra" is a dimension of performativity of organizing practices in relationships that "just happen and are not always the effect of intentional human actions". This metonymy applies to the academics thriving and co-existing in a unit without direct subscription to or success in obtaining funding, or in publishing massively, or in teaching many hours to numerous students, or in dedicating much time to institutional meetings and community service. However, all these demands intertwine in a set of managerial discourse and formal procedures, emphasizing the need for a vital "bidding" in order to fund research, to teach "to a significant number of students", to "engage in the governance of Univia", and to "contribute to the visibility of Univia through mediatized community transfer activities" (managerial discourse of deans, general administrator, rectorate). Such institutional expectations are also considered by academics as resources increasing their legitimacy.

In order to apply for funding, academics try to form loose collaborations in order to create a "winning" project and thereby gain the "bid" for research. However, not all academics within Univia - and in other French-speaking universities - are able or even want to subscribe to these funding schemes. In a competitive environment, many academics at Univia are sustained in a sheltered "ecological niche" [3]. They survive, despite the pressures of managerial discourse and formal structures, because of their colleagues' "successes" in subscribing to this logic. This however depends upon the existence of more successful colleagues in research centers.

"As yearly reports of research centers show, some academic members obtain large grants that make up the research centers' incomes for research and infrastructural costs through providing salaries for researchers, but also project overheads and coverage of research costs" (55-year-old male, dean in STEM faculties).

"I am happy when someone gets a large grant in our research center, such as an ERC. It allows us to have young researchers, who can assume some animation of seminars, teaching and cooperative, free work of this kind" (42-year-old female, newly-tenured academic in $\mathrm{SSH}$ faculty).

Academics who are not involved in funded projects can however benefit from the successful entrepreneurship of peers. This equally applies to academics who do not publish innumerable scientific articles per year, and who do not teach more than 90 hours a year, 120 hours being a minimum in the Belgian French-speaking context. Even fewer academics enter into a total engagement in institutional service, such as department, faculty or university governance (becoming middle or top managers), or participating in heading teaching juries or programs. They can continue with their exclusive teaching tasks, or else take part in research projects without officially being part of any project team. On the other hand, academics employed in highly funded projects can negotiate a reduction of teaching. In this sense, not all academics are willing or able to align with the Entrepreneurship logic of action. Those same strategies can offer a "sheltered environment, without binding commitments" to the logics of action of Entrepreneurship, but also to Excellence and Omnipresence. But the ground for such connections is nurtured by the presence of the formal organizing mechanisms and institutions and their modes of fostering other experiences [3].

\subsection{Local Candidates in the "Secret Societies" of Academic Recruitment}

The "secrecy" metonymy [3] sheds light on how academics can collectively organize to circumvent the Excellence norm, as illustrated by the concrete strategy of candidate recruitment. The metonymy is the effect of the intra-action between what is said (and what can be said) and what should be kept unsaid; a secrecy that is enacted by trust, personal bonds and trading between what can be said and what cannot [3]. In Univia, the recruitment of a new academic consists of organizing processes that should stay hidden or unspoken, while all the time being situated in "transparent" meritocratic procedures (such as OTR-M). This could involve more or less illegal or morally disputable activities, or in our case contradictory and non-declared activities. So, secrecy is what is said, what can be said, and what should be left unsaid [3].

In a previous analysis of the recruiting practices ${ }^{9}$ of academic committee members [23], these members expressed managerial discourses pertaining to "excellence" throughout the recruitment process, which comprised two selection rounds. A first round aimed to select the best application files and CVs, and the second to select and interview few

9 This metonymy can also apply to other (publication, application, promotion) peer-reviewing activities. 
candidates. The president of the committee governs the process, and starts by choosing the members of the committee. The members are chosen in a given faculty, consisting of junior or senior academics occupying statutory positions or focusing on particular subject areas and scientific fields. But some members must be external to both the faculty and the university. These choices represent the precincts of "secret societies" in the form of institutional networks [11]. Moreover interviews with committee members and presidents have revealed the discourses pertaining to informal selection criteria.

"It is all about hiring the 'suitable' candidate, who will fit locally, despite the increasing presence of standardized equality policies, despite formal top-down recommendations pertaining to 'neutral' recruitment, despite 'excellence' discourses amounting to internationalization in recruitment that have led to the final selection" (46-year old male, academic, former president of three recruitment committees).

All this however, happens within the formal structures approved by the central administration and rectorate, which grant the committee members the right to keep their recruitment procedures a "secret", the right to invisibility within faculties and research centers, as written selection procedures do not require total organizational transparency.

"Academic recruitment is shown to have as such no standard procedures or rules, but rather informal rules of the game that are maintained in a precarious balance, so that the committee stays free to choose the person they want" (54-year-old male, academic, former member and president of five recruitment committees).

This margin of maneuver is preserved within the precincts of the Excellence discourse and procedures. In this margin there is a distinctive shadow practice: the preference for local over external candidates. These discourses of "the suitable candidate" often amount to knowing the candidate beforehand of choosing someone "trustworthy", and therefore known, someone "less risky", paired with a discourse of "few academic positions", the "difficulty of finding permanent positions once you are within the institution", and "needing to sustain local researchers" (various former recruitment committee members, academics and researchers).

Despite the persistence of formal practices like open external calls for academic positions, internal shadow recruitment practices of "known" insiders can fulfil on the one hand the committee's need to reduce the uncertainty of recruitment. On the other hand, it can fulfil the need for continuity and the professional progression of internal academic quasi-members - who will be called "the local candidates". Academic committee members, who are often senior members of a faculty, organize themselves to choose the candidate who fall into the centers' schemes of research, or they can choose the stream of research corresponding to the local candidate's profile, in order to preserve or reinforce internal cohesion and internal secret societies.

If their decisions and negotiations are made within the framework of formal recruitment procedures, Univia's central management ensures the relative "secrecy" of the selection.

During our empirical study, we have been refused to access procedural reports "in order to maintain secrecy and discretion" (quoting a 54-year-old female, secretary to rectorate).

Procedural writing up of the candidate selection process is ensured secrecy and is only subject to the approval by the top management, which rarely exercises its right to oppose or reject an applicant. The informal character of recruitment processes is therefore inscribed [6] in the central rules and enacted by the committees [46].

\subsection{Invisible Caring in the Liminal Grey Zone of Work Life Articulation}

The "liminal grey zone" metonymy [3] illuminates how academics can cope with the logic of action of Omnipresence, as illustrated by the example of the "the invisible carer (s)" [21] through which academics articulate their work and private lives. The grey zone described by Gherardi et al. [3] is a space and time of ambiguous definition and of mutable relations, such as the liminal space of the threshold. Here organizing takes place at the intersection of formal rules and practices in order to get things done. The main part of our research project [21] consisted in analyzing how academics try to articulate their work and private life. Some early stage academics (within 5 years of completing their $\mathrm{PhD}$ ) explain how they use international mobility - required to progress in their career to gain valuable experiences with and for their family. However, depending on mobility funding grants, or on the economic situation of the host country and university, some must try to "survive" or "have a decent" family life on the grant (according to 30 to 35-year-old female and male postdoctoral researchers in STEM and SSH faculties). Mobility, while climbing the career ladder, also means being ready to change institutions, depending on where you can find an academic position.

Relocating with one's family and kids also means adapting together to a different educational, work and parenting system. Family configurations, flexibility and support systems contribute to the enactment of this liminal grey zone of work life articulation.

"The research demands, the high investment of time, is not always compatible with the life of a parent. For example, during our research stay in Oxford, my husband and child had to move abroad (my husband worked from Oxford) and we had to often apply to child care services" (36-year-old female academic in STEM faculty).

Young academics also try to win research funding to obtain financial means in order to support family life, especially if both partners are not professionally stabilized with permanent jobs. In most cases, academics who are parents try to maintain the balance by keeping their children with child care services or family support. They also speak about having supportive partners who can assume child caring and household chores. Working from home is another liminal zone, whereby the translation of the discourse on flexible working hours and spaces prospers in a blurry grey zone in order to maintain a precarious balance. 
"Work/family balance is not always easy and my work requires a total involvement. Although I work from home two or three days a week, this permits me to get things done at home, but not always in a satisfactory way" (32-year-old female, academic, in SSH faculty).

Such a strategy finally allows the young academic to continue working, or to split work time for family care purposes. The logic of action of the omnipresent worker is also enacted through non-declared working time; doing reading-writing-emailing tasks 24 hours a day, even during holidays; parental and maternity/paternity leaves that are non-declared and are again vice-versa discursively translated to feed the image of the "ideal/excellent academic", who never stops working, and is always available.

"My husband and I waited to have a child until after I had my permanent position, because we felt freer to think about a child. It's not so much about reconciling work and family life, but rather constructing both at the same time" (40-year-old female, academic at SSH faculty).

Young academics are also adopting some strategies to take on multiple responsibilities within the organization, while some senior peers develop strategies of self-preservation.

A newly appointed academic told us that she was highly engaged institutionally during her tenure-track period, as she was co-director of a research center, despite her unstable and non-permanent research contract; she invested in this task to a very high degree and had a burn-out with severe health issues. As co-director, she also supervised informally many young researchers, PhDs, without being formally involved in their theses. Other young academics speak about how boundaries of research and teaching work are sometimes hard to set and how this can spill over into other life spaces and times; working during long travelling hours, evenings and weekends to meet deadlines (30 to 39-year-old females and males, academics at SSH and STEM faculties).

At Univia, junior academics assume multiple institutional responsibilities, such as taking the presidency of a Bachelor or Master degree Jury, and being part of various internal and external working groups. They are very productive through developing innovative projects, getting funds and grants, publishing in A-rank journals, promoting PhDs, developing international networks, being mobile and teaching more than 150 hours to a large number of students. At the same time, well-established academics (ordinary professors aged 50+) specialize in governance inside (as dean or vice-dean, rector or vice-rector) or outside the university (as a ministerial advisor, member of an agency, head of a start-up firm, etc.) and are spared Omnipresence in order to focus on specific pillars or tasks. In this sense, many new or young academics can take care of multiple academic tasks, while remaining quite invisible in this caring stance towards the organization. On the other hand, arguably, some senior academics care for the organization by assuming a specific pillar in a more exclusive way.

These examples show the liminality-based management of thresholds [3] between academic work and private life. The important liminality operating through the mutual enactment and translation of the Omnipresence logic of action is that the care dimension [47] in the life spaces of the academic/researcher remains invisible, and sustains the omnipresent academic. We can thus speak of "invisible caring", because academics and researchers, and their families, try to work around and with the Omnipresence logic of action through this grey zone, in order to survive firstly as members of academic organizations and, in parallel, to co-exist as members of another type of organization: their family. The "invisible caring" ideal-type strategy therefore illustrates how academic players renegotiate the lines between work and family in order to follow the "greedy institution" rules of the game. They also renegotiate the lines between the four pillars of academic work. In so doing, they reinforce the managerial discourse of Omnipresence and its formal inscription [6].

\section{Conclusion}

This article illustrates how academics can pretend to align with EEO logics of action through shadow organizing [3] and therefore reproduce the discursive and formal structures of universities. Academics are playing and applying the rules of the game while also disengaging (explicitly, implicitly, secretly) from them. These practices therefore contribute in preserving the three identified academic logics of action. This paper also shows that the more numerous academic logics of actions are, the more they are discursively supported by "faith" in them, the more they are materially inscribed in formal tools and procedures, and the more they will be "secretly" circumvented by academics. As a consequence, the more academics pretend as if they - can - align with these logics of action, the more academic organizations are hypocritical [48]. In this sense, this analysis gives a new insight of the already massively studied shift toward managerial bureaucracy, which creates new managerial roles in old hierarchies between top managers (Rectoral/central governing team members, HR administrative staff and support to the Rectoral team), middle managers (Deans of Faculties, Presidents of Institutes/Departments) and local (self/unit) managers (academics).

The analytical framework informing both the interview guides and the analytical work proposes to distinguish between three constitutive dimensions of organizations [2]. It illuminates the tension between two different uses of knowledge: the top management's vertical use of inscribed knowledge, which aims at increasing the competition at the bottom, through a strategic emphasis on the need for excellence in the each of the three pillars and in omnipresence, on the one hand; and the self-managing academics' horizontal translation of enacted knowledge, which aims at increasing their expertise in one (sometimes in two) pillars (being specialized in research, or in teaching, or in community services), on the other hand. However, many academics share the feeling that top management's expectations, while reinforcing (an illusion of) omnipresence, instead favor (the illusion of) polyvalence and threaten the interdependence and cooperation usually uniting specialists. In a highly competitive working context where 
specialists can't be omnipresent, the risk of anomie and burnout is high, although top and middle management are legally responsible to prevent this risk.

In this context, however, this article demonstrates through the use of the shadow organizing framework (Gherardi et al., 2017) that the professional caring dimension of academic work is surviving, albeit "secretly": excellence and funding do not structure everything; not everyone becomes an excellent and heavily funded researcher. On the contrary, more and more students, in more and more teaching programs, are being taught by fewer academics. Moreover, institutional life is becoming increasingly greedy, through NPM, increasing administrative workload, and required meetings.

This paper shows how EEO logics of action are being sustained and reproduced despite and by shadow organizing strategies. Entrepreneurship is reproduced by academics who preserve their autonomy in the sheltered niche of peers who subscribe to Entrepreneurship "successfully". Excellence is maintained as a logic of action, as academics negotiate "the perfect candidate" secretly in discursively and formally protected procedures. Omnipresence in a greedy organization is being fed by academics who practice a liminality-based management of thresholds [3] between academic work and private life by "invisible caring".

As a result, academics are constantly negotiating between sobriety and bidding, localism and excellence, omnipresence and caring. This organizing work reflects, at various institutional levels (unit, department, faculty, university), the tension experienced by academics between two organizational models: a professional-bureaucratic, and a managerial-bureaucratic one. This tension, its mechanisms and consequences are being made and kept invisible, as they are shadow organizing processes. In this sense, the EEO are being fostered by the invisibility of sobriety, localism and caring logics of action.

\section{References}

[1] Dubois-Shaik, F., Fusulier B and Vincke C (2018) The Leaky Pipeline and Interrelated Phenomena in Six European Countries. In: The Precarisation of Research Careers: a Comparative Gender Analysis, eds Murgia, Annalisa, and Barbara Poggio, chapter 6. London: Routledge, doi:https://doi.org/10.4324/9781315201245.

[2] Friedberg, E. (2012). La sociologie et le management des organizations. Seminar presentation, Liège, 23 March.

[3] Gherardi, S., Jensen, K. \& Nerland, M. (2017). Shadow organizing: a metaphor to explore organizing as intra-relating. Qualitative Research in Organizations and Management: An International Journal 12 (1): 2-17, DOI: 10.1108/QROM-06-2016-1385.

[4] Crozier, M. (1964). The Bureaucratic Phénomenon, Chicago, University of Chicago Press.

[5] Kuty, O., \& Dubois, C. (2019). De la valeur à la norme: Introduction à la sociologie. Louvain-la-Neuve : De Boeck.

[6] Freeman, R. \& Sturdy, S. (2014). Knowledge in policy:
Embodied, inscribed, enacted. Bristol: Policy Press.

[7] Czarniawska, B. (2004). Narratives in Social Science Research: introducing qualitative methods. London: SAGE.

[8] Fairclough, N. (1993). Critical discourse analysis and the marketization of public discourse: The universities. Discourse $\begin{array}{lllll}\& & \text { Society } & 4 & \text { (2): } & 133-168 \text {, }\end{array}$ https://doi.org/10.1177/0957926593004002002.

[9] Fallon, C. (2014). Des chiffres de la politique à la politique du chiffre/ le cas des réformes du financement de la recherche dans les universités belges francophones. Reflets et perspectives de la vie économique 53 (2): 113-131, https://www.cairn.info/revue-reflets-et-perspectives-de-la-vieeconomique-2014-2-page-113.htm.

[10] Musselin, C. (2017). La grande course des universités. Paris: Presses De Sciences Po.

[11] Van den Brink, M. \& Benschop, Y. (2012). Gender practices in the construction of academic excellence: Sheep with five legs. $\begin{array}{llll}\text { Organization } & 19 & \text { (4): } & \text { 507-524, }\end{array}$ https://doi.org/10.1177/1350508411414293.

[12] Gläser, J. \& Serrano Velarde, K. (2018). Changing Funding Arrangements and the Production of Scientific Knowledge. Minerva, 56 (1): 1-10, DOI: 10.1007/s11024-018-9346-4.

[13] Kallio, K. M., Kallio, T., Tienari, J. \& Hyvönen, T. (2016). Ethos at stake: Performance management and academic work in universities. Human Relations 69 (3): 685-709, https://doi.org/10.1177/0018726715596802.

[14] Ylijoki, O. H. (2005). Academic nostalgia. A narrative approach to academic work. Human Relations 58 (5): 555-576, https://doi.org/10.1177/0018726705055963.

[15] Engwall, L. (2007). Universities, the state and the market. Higher Education Management and Policy 19 (3): 1-18.

[16] Chatelain-Ponroy, S., Mignot-Gérard, S., Musselin, C. \& Sponem, S. (2018). Is Commitment to Performance-based Management Compatible with Commitment to University "Publicness"? Academics' Values in French Universities. Organization Studies 39 (10): 1377-1401.

[17] Benner, M. \& Sandström, U., (2000). Institutionalizing the Triple Helix: Research Funding and Norms in the Academic System, Research Policy, 29: 291-301.

[18] Etzkowitz, H. (2010). The Capitalization of Knowledge: A Triple Helix of University-Industry-Government. Ed. (with Viale). Cheltenham: Edward Elgar.

[19] Meyer, M. (2003). Academic entrepreneurs or entrepreneurial academics? Research-based ventures and public support mechanisms, R\&D Management, 33 (2): 105-115.

[20] Paradeise, C., Reale, E., Bleiklie, I. \& Ferlie, E. (Eds.) (2009). University governance. Dordrecht: Springer.

[21] Dubois-Shaik, F. and Fusulier B (2017) Understanding gender inequality and the role of work/family interface in contemporary academia: an introduction. European Education Research Journal 16 (2-3): 99-105, https://doi.org/10.1177/1474904117701143.

[22] Whitley, R., Gläser, J. \& Engwall, L. (Eds.) (2010). Reconfiguring knowledge production: Changing authority relationships in the sciences and their consequences for intellectual innovation. Oxford: Oxford University Press. 
[23] Dubois-Shaik, F., Fusulier F, and Lits G (2019) L'excellence académique entre "nomination" et "compétition". SociologieS. Dossiers, Universités : les politiques d'égalité entre femmes et hommes à l'heure de l'excellence, mis en ligne le 27 octobre 2019, https://journals.openedition.org/sociologies/.

[24] Czarniawska, B. \& Genell, K. (2002). Gone shopping? Universities on their way to the market. Scandinavian Journal of Management $18 \quad$ (4): 455-474, DOI: 10.1016/S0956-5221(01)00029-X.

[25] Lamont, M. (2009). How Professors Think: Inside the Curious World of Academic Judgment. Cambridge: Harvard University Press.

[26] Hammarfelt, B., de Rijcke, S. \& Wouters, P. (2017). From eminent men to excellent universities: University rankings as calculative devices. Minerva 55 (4): 391-411, https://doi.org/10.1007/s11024-017-9329-x.

[27] Power, M. (2015). How accounting begins: Object formation and the accretion of infrastructure. Accounting, Organizations and Society 47: 43-55.

[28] Paradeise, C. \& Thoenig, J. C. (2013). Academic institutions in search of quality: Local orders and global standards. $\begin{array}{lllll}\text { Organization } & \text { studies } & 34 & \text { (2): } & \text { 189-218, }\end{array}$ 10.1177/0170840612473550.

[29] Scully, M. A. (1997). Meritocracy. In: Blackwell Encyclopedic Dictionary of Business Ethics. Werhane, Patricia Hogue, and R. Edward Freeman, 413-414. Oxford: Blackwell Publishers.

[30] Merton, R. K. (1973). The sociology of science: Theoretical and empirical investigations. University of Chicago Press.

[31] Hicks, D. \& Katz, J. S. (2011). Equity and excellence in research funding. Minerva 49 (2): 137-151.

[32] Watermeyer, R. \& Olssen, M. M. (2016). 'Excellence' and exclusion: the individual costs of institutional competitiveness. Minerva 54 (2): 201-218.

[33] Kasten, K. L. (1984). Tenure and merit pay as rewards for research, teaching, and service at a research university. The Journal of Higher Education 55 (4): 500-514.

[34] Park, S. M. (1996). Research, teaching, and service: Why shouldn't women's work count? The Journal of Higher Education, $67 \quad$ (1), 46-84 https://doi.org/10.1080/00221546.1996.11780249.
[35] Geurts, P., \& Maassen, P. (2005). Academics and institutional governance. In: The Professoriate: Profile of a profession, ed. Anthony Welch, 35-58. Dordrecht: Springer.

[36] Macfarlane, B. (2007). Defining and rewarding academic citizenship. Journal of Higher Education Policy and $\begin{array}{llll}\text { Management } & 29 & \text { (3): } & 261-273 \text {, }\end{array}$ https://doi.org/10.1080/13600800701457863.

[37] Bleijenbergh, I. L., Marloes, Lv. E. \& Vinkenburg, C. J. (2012). Othering women- fluid images of the ideal academic. Equality, diversity and inclusion- An international journal 32 (1): 22-35.

[38] Coser, L. A. (1974). Greedy Institutions. New York: The Free Press.

[39] Fusulier, B. \& Nicole-Drancourt, C. (2015). Pursuing Gender Equality in a "Multi-Active" Society. Global Dialogue, 5 (1), 30-31.

[40] Olsen, J. P. (2010). Governing through institution building: Institutional theory and recent European experiments in democratic organization. Oxford: Oxford University Press.

[41] Friedberg, E. (1997). Local orders: Dynamics of organized action. Greenwich: Jai Press.

[42] Latour, B. \& Woolgar, S. (1986). Laboratory Life: The Construction of Scientific Facts, Princeton University Press.

[43] Brunsson N (1989) The organization of hypocrisy: talk, decisions, and actions in organizations. New York: Wiley.

[44] Bercovitz, J. \& Feldman, M. (2008). Academic Entrepreneurs: Organizational Change at the Individual Level. Organization Science 19 (1): 69-89, doi 10.1287.

[45] Van den Brink, M., Benschop Y. \& Jansen, W. (2010). Transparency in academic recruitment: a problematic tool for gender equality? Organization Studies 31 (11): 1459-1483, DOI: $10.1177 / 0170840610380812$.

[46] Weick, K. E. (1995). Sensemaking in Organizations. Oaks: Sage.

[47] Fusulier, B. (2016). Faire une carrière scientifique aujourd'hui. Quelques clés de lectures et critiques. In: L'évaluation de la recherche en question ( $s$ ). eds Leclercq $\mathrm{B}$, Timmermans $\mathrm{B}$, Clerbaux B, Bersini H, Hudon M, and Zaccai E, 101-110. Bruxelles: Académie Royale de Belgique.

[48] Brunsson, N. (1989). The organization of hypocrisy: talk, decisions, and actions in organizations. New York: Wiley. 